\title{
norden
}

Sustainable Development in Practice

Examples from the Nordic countries
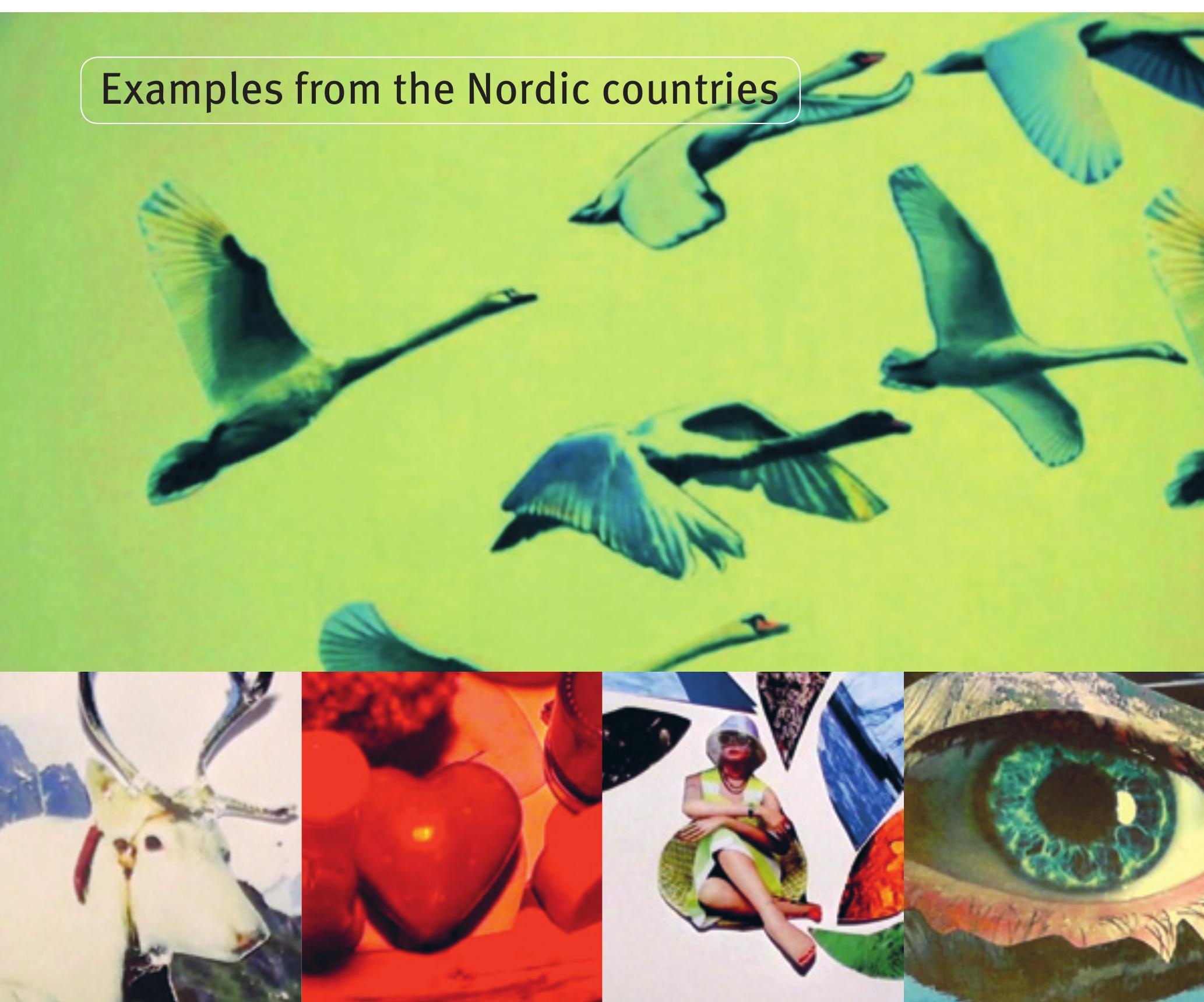


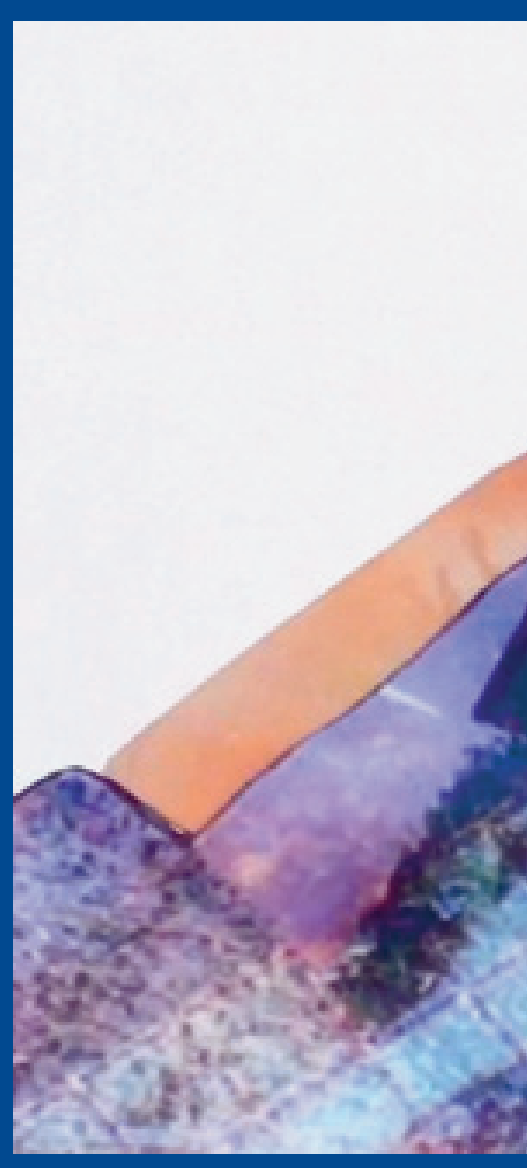




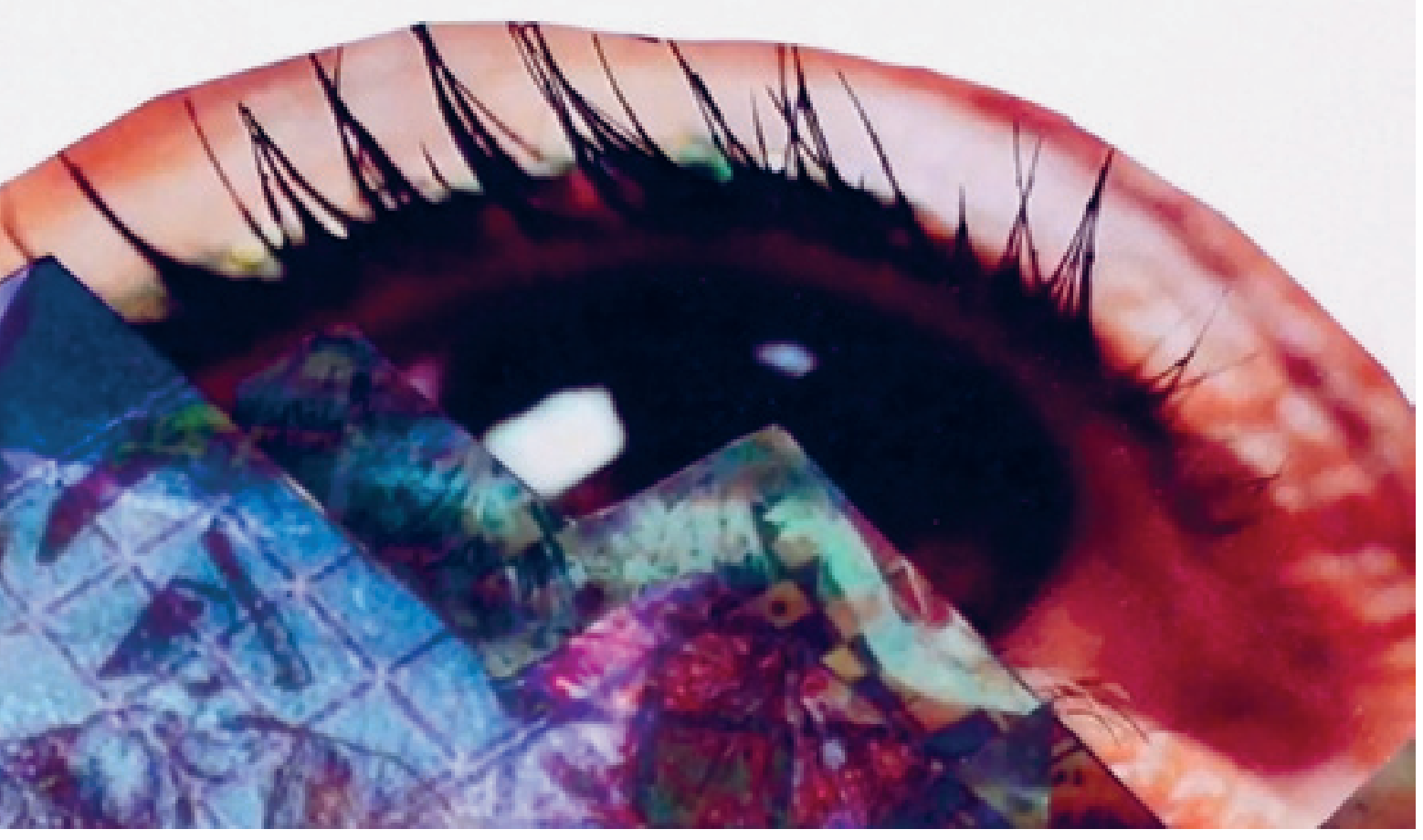




\section{Sustainable Development in Practice}

Examples from the Nordic countries

ISBN: 978-92-893-2355-0

DOI: $10.6027 / A N P 2012-726$

ANP 2012:726

(C) Nordic Council of Ministers

Layout: Erling Lynder / Nordic Council of Ministers Translation: Tam McTurk

Cover photo: House of Futures and Beate Nøsterud Photo: House of Futures, Beate Nøsterud and Nordbild Print: Rosendahls Schultz-Grafisk, Albertslund Copies: 3000

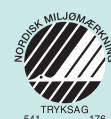

\section{Nordic co-operation}

Nordic co-operation is one of the world's most extensive forms of regional collaboration, involving Denmark, Finland, Iceland, Norway, Sweden, and the Faroe Islands, Greenland, and Åland.

Nordic co-operation has firm traditions in politics, the economy, and culture. It plays an important role in European and international collaboration, and aims at creating a strong Nordic community in a strong Europe.

Nordic co-operation seeks to safeguard Nordic and regional interests and principles in the global community. Common Nordic values help the region solidify its position as one of the world's most innovative and competitive.

\section{Nordic Council of Ministers}

Ved Stranden 18

1061 Copenhagen $\mathrm{K}$

Telephone (+4533960200

www.norden.org 


\section{Sustainable Development in Practice Examples from the Nordic countries}

7 Preface

8 Sustainable development - a common priority for the Nordic countries

11 Joint Nordic initiatives to meet the climate challenge

19 Towards more sustainable consumption and production

27 Welfare and sustainable development go hand-in-hand

30 Knowledge and participation vital for sustainable development 


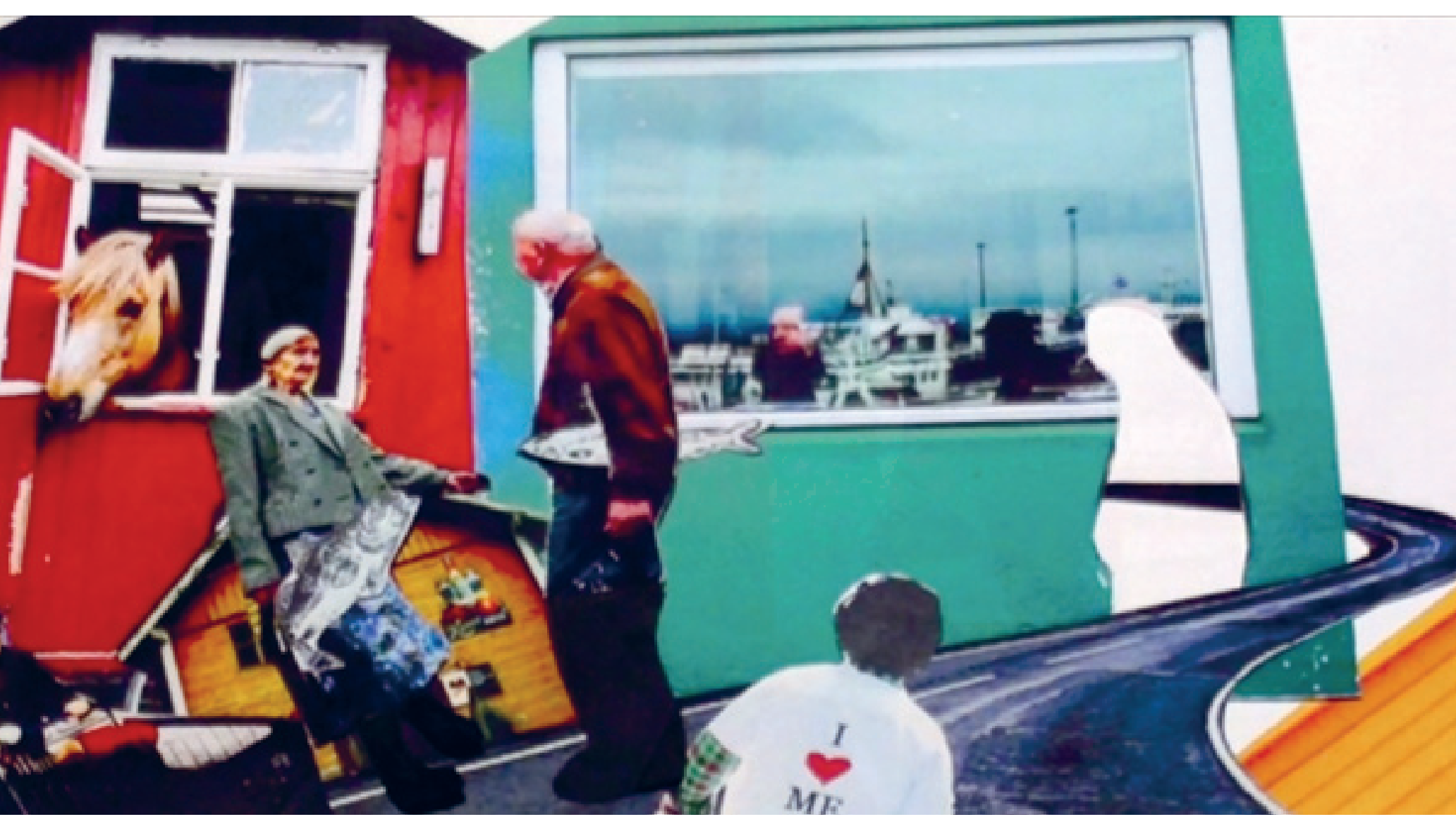




\section{Preface}

"Sustainable development is development that meets the needs of the present without compromising the ability of future generations to meet their own needs."

This is the short and precise definition of sustainable development applied by the Brundtland Commission in its report, Our Common Future, in 1987. This definition from the Brundtland Commission continues to form the basis for the work on sustainable development in the Nordic countries, while broad international engagement and collaboration continues, and is perhaps now more important than ever.

To be sustainable, society must develop and policies be driven with a dynamic holistic perspective; what I do today influences what you can do tomorrow, and what you want to do tomorrow has consequences for what someone else can do the next day. Everything is linked.
The Nordic countries are generally frontrunners in international aspects of the state of the environment and society. In recent decades, we have successfully shown that economic prosperity and a high standard of welfare can be combined with sustainable use of resources and management of the environment.

A great strength is that the open Nordic social structure creates a solid platform for discussion, listening and learning, all of which are necessary for sustainable development. The Nordic success is also based on, for example, initiatives to develop a high-class educational system, as well as research and development, good administration and smooth-running service systems, responsible and innovative enterprises, and a functioning civil society. A strong tradition of collaboration also helps.

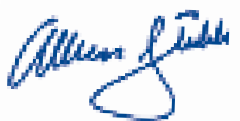

Alexander Stubb

Minister for Nordic Co-operation Finland comparisons that measure various
At the same time, we cannot rest on our laurels. We must look ahead and constantly strive to develop more sustainable societies. We can and will improve our sustainable solutions. What is needed is an innovative approach, continued commitment at local, regional and global levels, greater exchange of experiences and knowledge, and clear signals from the decision-makers. The colour of future successes is green, not least in terms of the environment, but also in terms of a sound and competitive economy that enables social prosperity.

Nordic co-operation on sustainable development is based on a global perspective. Global issues are also local issues, and vice versa. In this brochure, we want to share our Nordic experiences and give examples of our work on sustainable development. Our hope is that the brochure will inspire increased regional collaboration on sustainable development, both in the Nordic region and between other regions all over the world.

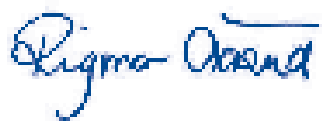

Rigmor Aasrud

Minister for Nordic Co-operation Norway 


\section{I}

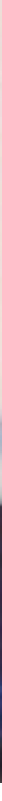




\section{Sustainable development - a common priority for the Nordic countries}

The Nordic countries are currently facing a number of common challenges - globalisation, the development of the information society, ageing populations, and unsustainable consumption and production patterns with consequences such as climate change. These call for joint initiatives to secure a safe, healthy and dignified life for present and future generations. In order to meet these challenges in the best possible way, and in order to make optimal use of the opportunities they present, the Nordic countries are working closely together to promote sustainable development in the region.

Collaboration is organised through the Nordic Council of Ministers, the official co-operation body of the Nordic governments. The Nordic Council of Ministers launched its first sustainable development strategy in 2001, probably the first regional SD strategy in the world.

Nordic co-operation on sustainability supplements national initiatives, and focuses on areas where we can collaborate to generate mutual Nordic synergies and added value. The collaboration will improve expertise and the efficient use of resources in the Nordic region. The crosssectoral approach is the key to our success, and we will always strive to identify solutions that benefit everyone involved.

In recent years, Nordic collaboration on sustainable development has focused on climate and renewable energy, sustainable consumption and production, welfare issues and education and research, as reflected in this publication.
An important instrument in the work on the sustainability strategy is the Nordic sustainability indicators. The indicators are used to monitor trends in the Nordic countries, and to compare development between the Nordic countries and in an international context. Some of the indicators are presented in this brochure, and more are shown on the Nordic Council of Ministers website.

www.norden.org/sd

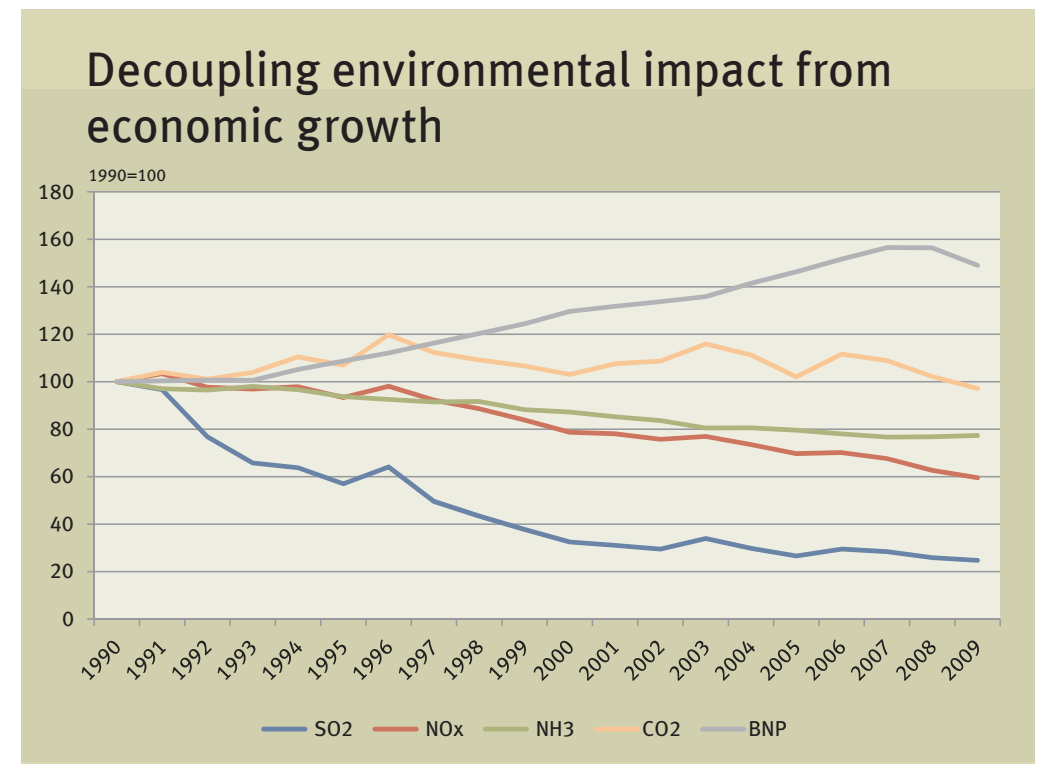




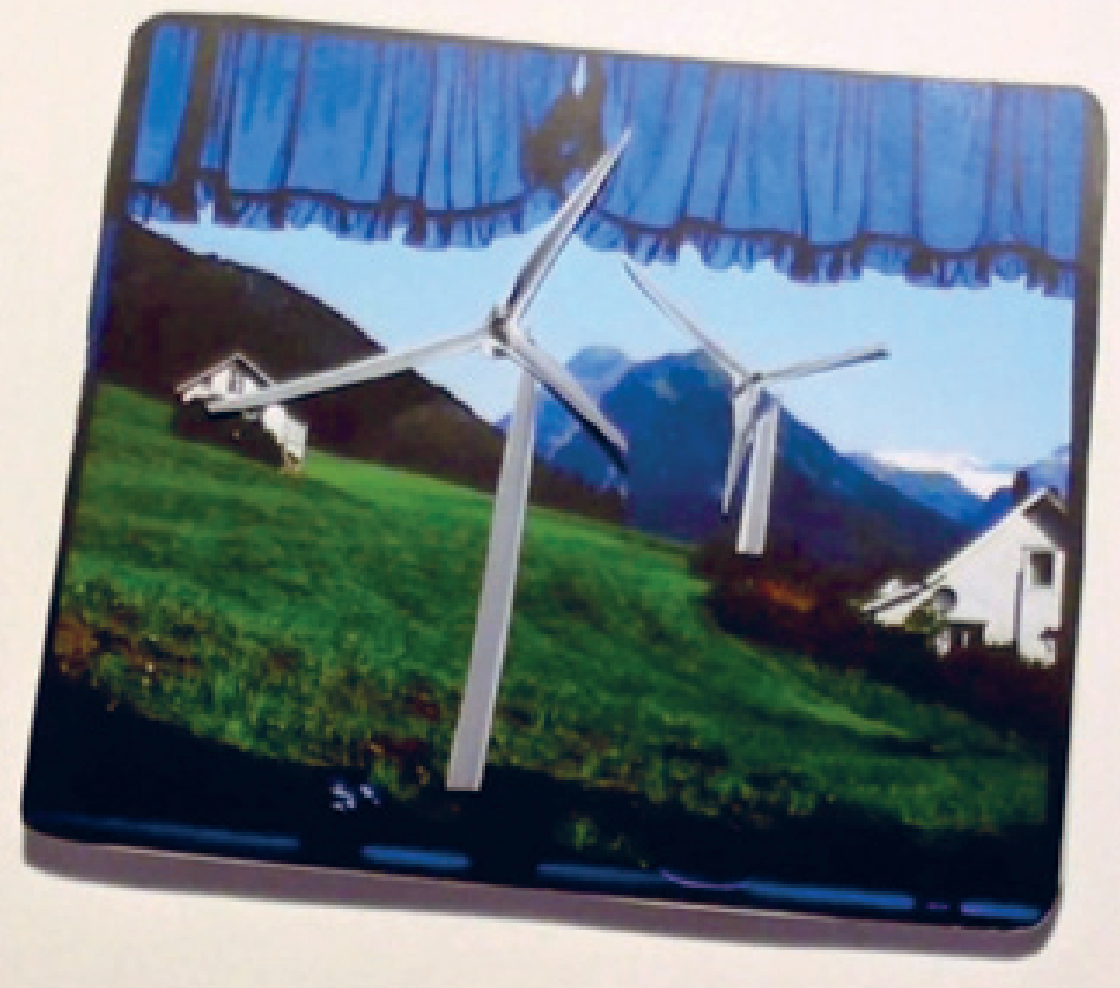




\section{Joint Nordic initiatives to meet the climate challenge}

Through sustainable utilisation of natural resources, the Nordic countries will respond to the challenges presented by climate change, and preserve biological diversity and improve its status in the region. In order to reduce their contribution to global warming, the Nordic countries have an objective to substantially reduce emissions, both nationally and within the framework of the UN and $\mathrm{EU}$, and to improve the efficiency of energy use. The Nordic countries - public authorities and individuals as well as the business community will prepare for new living conditions brought about by climate change.

\section{Nordic expertise and impact in climate issues \\ The UN Climate Conference in Cancún 2010 resolved to keep global warming below two degrees, a resolution that requires compre- hensive action by all countries. The developed countries have promised to support the developing countries in this enormous task by building up capacity and transferring technol- ogy, and through financing.}

As part of the work in tackling the climate issue, the Nordic countries have decided to finance a new programme to reduce emissions, the Nordic Partnership Initiative on
Up-scaled Mitigation Action, NPI. The programme will help Peru and Vietnam reduce their emissions in the sectors responsible for major pollution - waste management and cement manufacture.

NPI shows how international climate financing can be better reconciled with more intensive sector-based measures in developing countries. The objective is to build up the host country's capacity to evaluate, structure and implement nationallyappropriate measures (NAMA, Nationally Appropriate Mitigation Actions) that utilise international financing and possible new market mechanisms. Another aim is that the Nordic programme can serve as a model for measures in other sectors in the future.

\section{www.norden.org/npi}

\section{Arctic region affected by climate change}

Much of the Nordic land and sea areas lie within the Arctic region. Consequently, the Nordic Council of Ministers is strongly engaged in issues that concern this unique and harsh, but so vulnerable, area.

Climate change has brought about extensive changes in the Arctic. In order to understand development and to plan for a sustainable future in and outside the region, sound knowledge is required about the processes, circumstances and challenges that affect the area. The Nordic Council of Ministers Megatrends project is reviewing a selection of the processes that affect the potential for sustainable development in the Arctic. The project identifies nine different development tendencies that are so powerful that they can fundamentally change our societies - from local to global level. These megatrends can change our way of living and thinking, and so must be included in our deliberations when we are planning for a sustainable future.

Most of the megatrends that influence the Arctic areas are considered in the diversified collaboration in the Nordic Council of Ministers. A follow-up to the report, in the form of practical initiatives, is expected to help promote sustainable development in the Arctic. Examples of measures may involve environment and energy issues, welfare and health of the Arctic population, and demographic challenges in the Arctic communities.

$$
\begin{aligned}
& \text { www.norden.org/ } \\
& \text { en/publications/ } \\
& \text { publikationer/2011-711 }
\end{aligned}
$$




\section{Sustainable development from a gender equality perspective}

The debate about climate change tends to focus primarily on technological and economic aspects of climate change, with less focus on social and human aspects. But women and men influence, and are influenced by, climate and climate change in different ways. Transport, communication and waste management are examples of areas where differences can be seen between men's and women's habits and attitudes. The Nordic Council of Ministers project Equality and Climate Change will increase awareness, understanding and knowledge of climate change and sustainable development from a gender equality perspective.

The aim is that the project will stimulate dialogue about sustainable development, climate and gender equality at local, regional, Nordic and global level. Project activities include seminars and sideevents in which public authorities, politicians, researchers and NGOs can meet and discuss problems and solutions. The project will also present local solutions for how women and men can promote sustainable development by changing their behaviour patterns.

A new Nordic electronic knowledge platform, Equal Climate - Gen- der and Climate Change from a Nordic Perspective, focuses on the relationship between gender, consumption patterns, carbon dioxide emissions, knowledge and decision-making. The platform compiles information about the theme, disseminates practical examples, describes the activities in the Nordic countries, the Faroe Islands, Greenland and Åland, and follows up specific recommendations from the Nordic Summit Declaration 2009.

www.equalclimate.org www.norden.org/equality 


\section{Exchange of information between municipalities - a route to climate-friendly solutions}

The municipalities hold a key position in the work of the Nordic countries to manage climate change. The municipalities fully bear the responsibility involved in this key position, according to an analysis carried out by the Nordic project, Nordic Climate Cooperation on the Municipality Level (NOBILITI). For example, more than half of the municipalities have implemented comprehensive measures to reduce energy consumption, taken measures to manage increased rainfall quantities, and/or redirected urban planning towards greater sustainability.
But the NOBILITI analysis also points out unutilised potential - the municipalities could learn much more from each other.

Climate initiatives implemented at municipal level throughout the Nordic region do have many similarities, yet municipalities do not always learn from the experiences of others. A result is that many municipalities often "reinvent the wheel" in their various climate initiatives - instead of learning from and building on the practical experiences and solutions of other municipalities.

In order to simplify and encourage greater exchange of ideas and experiences between the various Nordic municipalities, NOBILITI has arranged a conference for the municipalities. A catalogue will be compiled of successful municipal climate projects, including the success factors that are most significant to any given municipal climate project - regardless of whether the project involves an adaptation or reduction measures/energy optimisation. The catalogue will contain ideas and addresses relating to climate work carried out in Nordic municipalities, and aims to promote greater collaboration over national and municipal boundaries.

www.nobiliti.org 


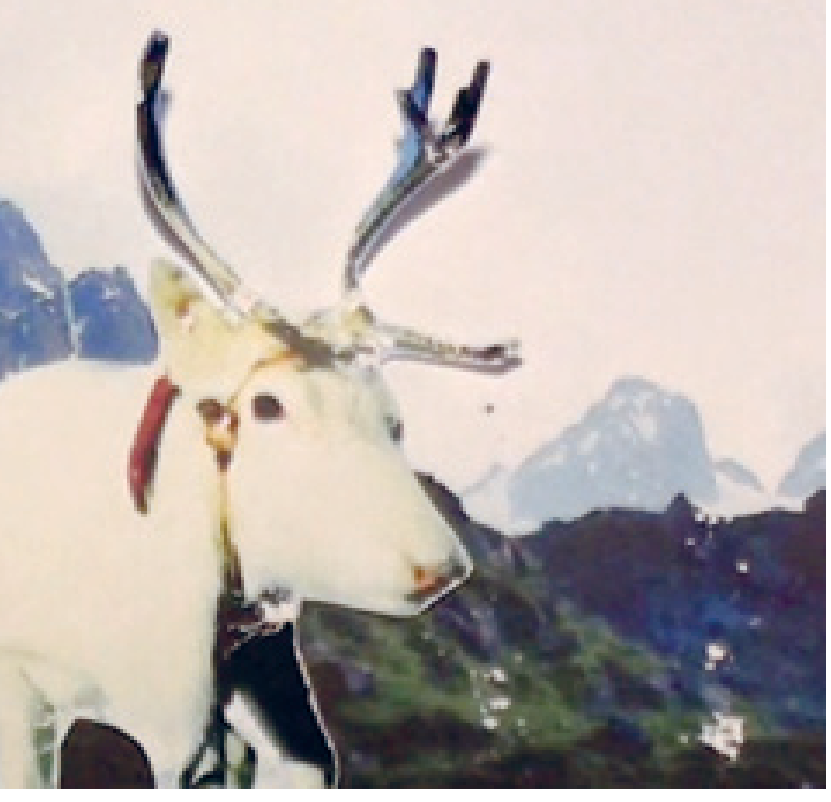

\section{Innovative energy municipalities}

The Nordic Energy Municipality 2011 project highlighted sustainable energy, green growth and energy-related climate efforts in the Nordic countries. The objective of the project was to recognise the Nordic municipalities that made a special effort to implement innovative energy projects. All Nordic municipalities were invited to take part in the competition.

During the competition period, 44 Nordic municipalities submitted applications, each describing a cutting-edge energy project that had been implemented. Of the applicants, 14 municipalities were nominated for the award of Nordic Energy Municipality.

www.nordicenergymunicipality.org
At the Globalisation Forum in October 2011, attended by the Nordic prime ministers, the Danish municipality Albertslund was named Nordic Energy Municipality 2011, chosen by an international jury. The Norwegian municipality of Drammen and the Swedish municipality of Lidköping were both given a special recognition of their projects. 


\section{Renewable energy - an important priority}

The Nordic countries already obtain much of their primary energy from renewable sources, but there is potential to substantially increase this proportion. The development of renewable energy sources is therefore an important aspect of the climate policy in all the Nordic countries, and many private companies in the region specialise in this field. Methods to promote the development of renewable energy include economic incentives, such as tax benefits for renewable energy sources. The countries also specifically support research and development projects in this field.

The task of the Working Group for Renewable Energy is to promote the use of renewable energy in the Nordic countries through joint initiatives that highlight how conditions and competition terms for renewable energy can be improved. This is done through exchange of information and experiences and through initiation of joint projects. Such projects may involve reviewing openings for greater collaboration in a given area.

One example is the study of how the Nordic countries can implement collaboration mechanisms relating to the EU Directive on
Renewable Energy. This project, which is run in the form of a dialogue between various stakeholders, both within and outside the Nordic area, has attracted great interest. In another study, the group is examining how Nordic collaboration can be increased in the field of solid biomass for energy use.

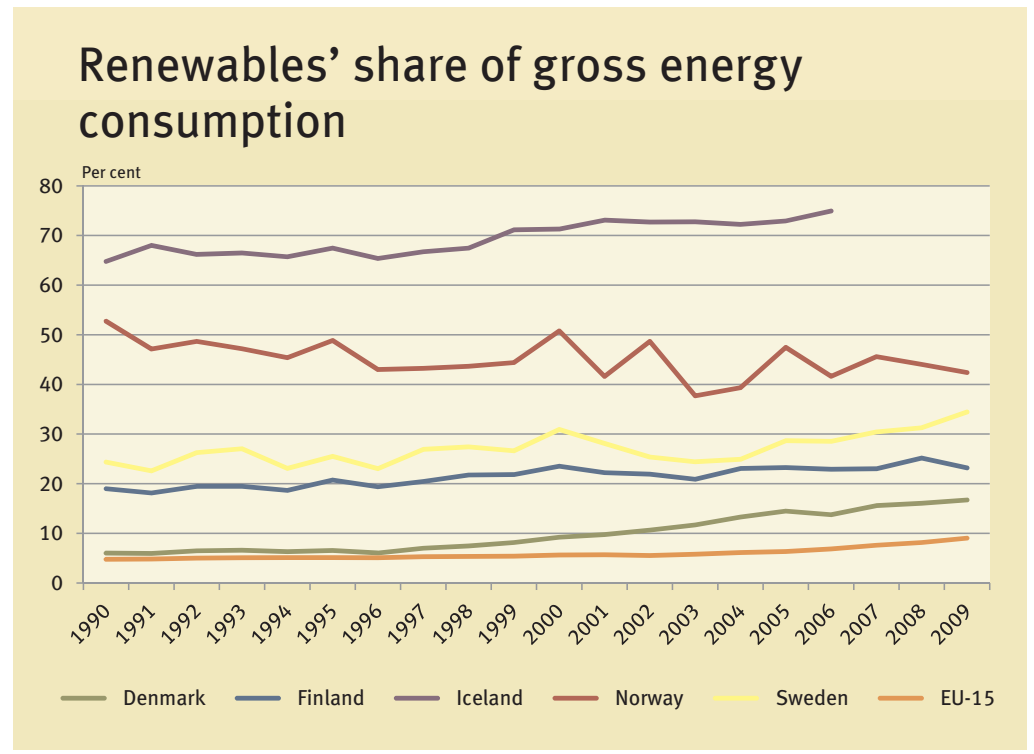




\section{NordVind project - inves- tigating potential for more wind power in the Nordic area}

The NordVind project is examining how wind power could be expanded in Denmark, Finland and Sweden. The project focuses on how public agencies in the countries are managing the expansion of wind power. Examples of topics studied are the political targets that have been formulated in relation to the expansion of wind power, and the nature of planning.

The project is also examining the official administration of wind power and the economic conditions, as well as the environmental aspects and research and development. The idea is that these factors will describe the opportunities and barriers relating to expansion of wind power in the three countries.

In the NordVind project, a working group has also been set up, com- prising representatives from various public agencies in the Nordic countries. The task of the working group is to promote coordination of the state planning processes relating to wind power.

\section{www.Nordvind.org}

\section{Nordic Built}

The Nordic countries are suppliers of important components for energy-efficient buildings, such as insulation material, pumps, windows and ventilation systems. Nordic architecture and design is highly regarded, and regulation is strict because of high political ambitions. Despite this, the Nordic construction sector has not fully capitalised on its advantages and the Nordic region has not positioned itself as a market leader in development and export of sustainable and energy-efficient concepts.

The objective of Nordic Built is to stimulate Nordic competitive concepts for sustainable construction - with particular focus on the existing building stock. Nordic Built is implemented in three modules, of which the first involves defining and creating a common identity and a common way forward. The second module is structured as a competition, where innovators from and beyond the construction sector will compete in renovating five buildings in the Nordic countries from an energy perspective. The third module will build on existing national initiatives and create scalable, competitive solutions for upgrading the existing building stock.

Together, the three modules will stimulate and accelerate comprehensive Nordic measures to solve the great challenge presented by the existing building stock.

www.nordicinnovation.org/ da/projekter/nordic-climatefriendly-buildings/ 


\section{Greenland invests in green energy}

Since the start of the 1990s, Greenland has systematically focused on greater use of renewable energy - both to ensure a constant supply of energy and to reduce the use of oil. Of the renewable energy sources, water power has greatest development potential in the country.

Today, there are four hydroelectric plants in operation on Greenland, and another is under construction in Ilulissat, the third largest town. The plant is expected to be brought into operation at the start of 2013 and will supply the town's population of 5,000 with renewable energy.

The switch to renewable energy involves a massive investment for Greenland. Consequently, in a country with only 56,000 inhabitants, the focus on sustainable energy is a very high political priority.

When the hydroelectric plant in Ilulissat is commissioned, 70 percent of public energy production will derive from renewable resources. This is the equivalent of over 40 percent of the total energy production, i.e. both public and private, on Greenland.

The state energy company Nukissiorfiit - with operational responsibility for the state-run hydroelectric plants - is also working to develop other methods that can reduce the use of fossil fuels. For example, the company has invested in hydrogen and fuel cell facility that will increase knowledge about hydrogen as an energy carrier. Hydrogen can be used to utilise the surplus capacity of Greenland's hydroelectric plants.

Two other current initiatives are a test project for electric cars in the capital, Nuuk, and an analysis of the use of pumped storage on Greenland. Campaigns are also run aimed at influencing consumer behaviour. 


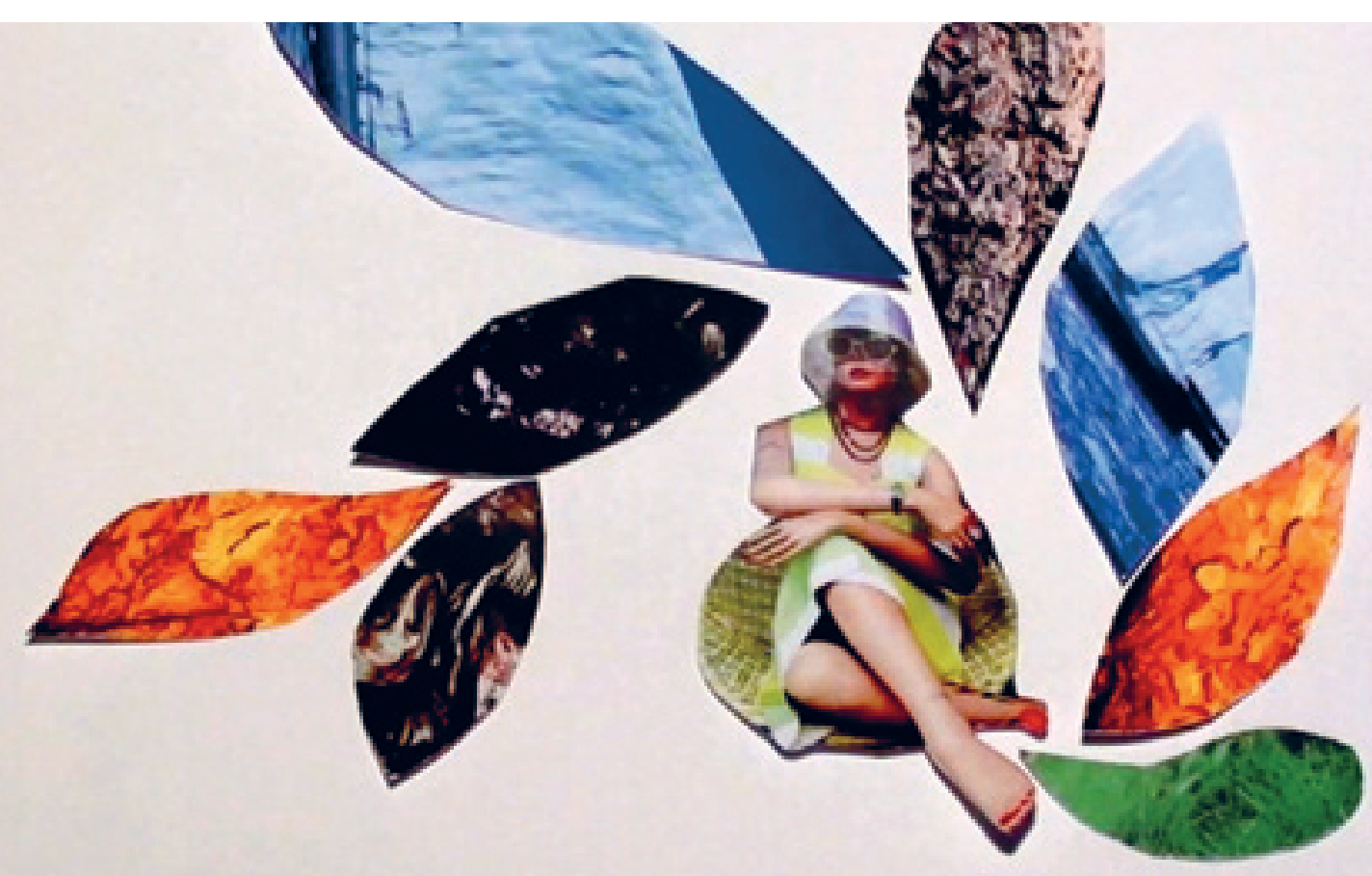




\section{Towards more sustainable consumption and production}

Economic growth promotes greater consumption, higher material welfare, raised living standards and improved health, but also brings new social and environmental challenges. When growth leads to overexploitation and pollution of ecosystems, this has strongly negative consequences for both the environment and people's health. Many of the environmental and health problems we see today are linked to unsustainable consumption and production of products and services, which has a negative impact on the ecosystems.

Well-functioning ecosystems are a must if we are to have access to ecosystem services like clean water, clean food and other biological raw materials. If we are to be able to feel and live well in the future, we must therefore protect our ecosystems. The Nordic Council of Ministers is working actively to create more sustainable consumption and production patterns in the Nordic societies.

\section{A social and economic perspective on ecosystems}

In recent years, there has been ever-increasing focus on the concept of ecosystem services, i.e. the vital services that our ecosystems offer, such as clean water, clean air and a healthy environment. The ecosystem services are also important for agriculture, forestry and other land-based sectors.

Healthy and well-functioning ecosystems are vital for strong economic growth and for preservation of biological diversity. The Nordic Council of Ministers is therefore working actively to develop instruments that enable Nordic countries to include consideration of ecosystems in their economic decision-making.

The TEEB Nordic project - an assessment of the state and

www.ieep.eu/work-areas/biodiversity/valuing-biodiversityand-ecosystem-services/2011/02/initiating-a-teebassessment-for-the-nordic-countries economics of the key ecosystem services in the Nordic countries - is assessing the socioeconomic role and the significance of ecosystems and biological diversity in the Nordic countries. The assessment is based on the UN global TEEB initiative, and aims to supplement the global review with more in-depth analysis at regional level.

TEEB Nordic will identify the key ecosystem services in the Nordic countries, investigate which services are most important for society, and investigate how the real (economic) value of nature in the long term can be included in political decision-making. Another aim is that the project will encourage more regional and national TEEB initiatives around the world. 


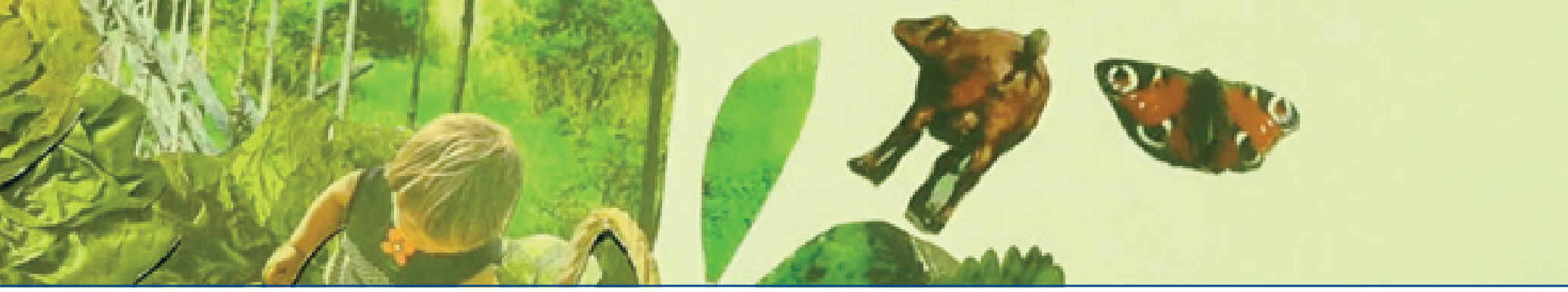

\section{Economic incentives to encourage new consumption and production patterns}

Regulation through environmental policy in the Nordic countries has undergone a dramatic change. The Nordic countries are frontrunners in a renewal process in which traditional environmental regulation in the form of standards and permits is broadening to include new market-based instruments, such as environmental taxes. One of the objectives of increased use of market-based steering is an attempt to actually put a price on environmental impact.
The Nordic countries are characterised by a relatively high tax burden. In general, the introduction of environment-related taxes has not increased the tax burden because the countries have focused on shifting taxes, i.e. taxes on employment have been replaced by environmental taxes. In some individual cases, taxes and charges have been earmarked for environment-related purposes. Environment-related charges and emission rights have also been used successfully. Particularly in climate policy, market-based instruments are playing an ever-increasing role in all Nordic countries.

The gradual restructuring of environment policy has successfully increased cost-effectiveness and reduced environmental impact in many areas. The Nordic experiences indicate that an ambitious environmental policy can be combined with sound economic development. 


\section{Environmental labelling - the Nordic Ecolabel success story}

The large arsenal of environmental policy instruments in the Nordic countries is not confined to economic instruments. The Nordic countries were also pioneers in environmental labelling and environmental management in industry. Consumption-based environmental issues have attracted greater attention, and collaboration between various players in this area is increasing.

The official Nordic environmental label, Nordic Ecolabel- also known as the Swan - was created in 1989. It is an important part of the Nordic environmental work, and helps to reduce the environmental burden caused by everyday consumption. The Nordic Ecolabel certification limits the environmental impact of goods and services throughout the life cycle, from raw material to waste. The certification criteria are strict in terms of climatic and environmental impact, but also in terms of function and quality. The Nordic Ecolabel will help guide Nordic consumers and buyers, enabling them to buy 'green' and thereby help reduce the environ-

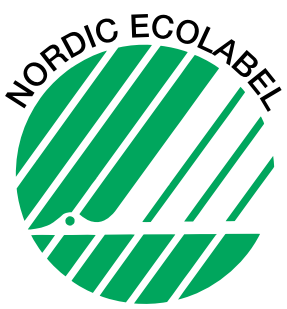

mental burden caused by their consumption. Pressure from consumers stimulates the producers to make more environmentally-sound products. The idea is that the Nordic Ecolabel will be an attractive and credible way for companies to use the environment as a com- 
petitive tool, and become a natural choice for consumers demanding more in terms of environment and quality.

Today, the Nordic Ecolabel is a well-known and appreciated envi- ronmental label. A recent survey showed that 94 percent of the Nordic population was aware of and recognised the Nordic Ecolabel as an environmental label. Over 2,000 Nordic Ecolabel licences have been issued so far, involving more than 6,000 products, and the number of licences is rapidly and constantly increasing.

www.nordic-ecolabel.org

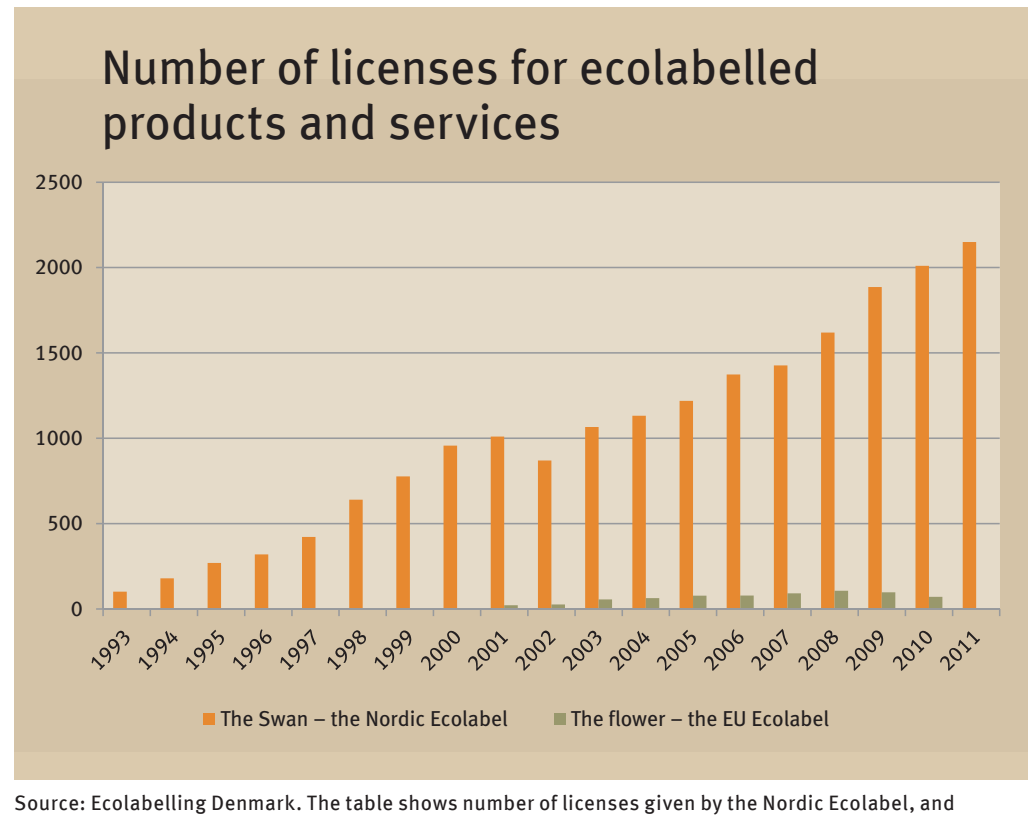

Source: Ecolabelling Denmark. The table shows number of licenses given by the Nordic Ecolabel, and number of licenses issued to Nordic producers by the EU Ecolabel. 


\section{Environmental labelling as a competitive advantage - growth of the Nordic Ecolabel in Iceland}

Iceland has been involved in the development of Nordic Ecolabel from the start but, despite this, the label has held quite a weak market position in the country. Consequently, in the past two years, the Icelandic Ministry for the Environment has invested heavily in the Nordic Ecolabel. This has brought immediate results - in 2008 only three Icelandic companies held the Nordic Ecolabel licence but today, four years later, the number has already grown to 19 and the trend is continuing.

At the same time, an increasing proportion of the Icelandic population is recognising the label. A Gallup survey carried out in December 2011 showed that 73 percent of the population recognises the Nordic Ecolabel. The recent economic problems in Iceland might seem to present an obstacle to the growth of the environmental label, but this does not appear be the case. In fact, companies seem to see the label as an important competition advantage. The printing and cleaning sectors, and recently the hotel sector, have led the development.

The public sector has a responsibility to promote ecolabelled companies and services. Because of its size, procurement in the public sector can influence the market and stimulate environmental production of goods and services. The public procurement centre has translated 16 environmental criteria that are used by all public organisations when procuring various products and services. In addition, each institution receives a personal visit from advisors that assist buyers in applying the environmental criteria, gather information about how far the institution has come, and provide training for staff. These visits have been positively received, and show that the public sector is open to, and eager to switch to, green purchases. 


\section{Green public procurement}

There is consensus in the Nordic countries that public procurement can be a powerful instrument in the work to direct our societies towards long-term sustainability. The public sector is a large consumer of goods and services: in the EU countries public procurements comprise 16 percent of the GNP. By considering environmental and social criteria when procuring goods and services, the public sector can promote a positive development in the green and socially sustainable market sector.
Public procurement has been shown to be an important driver in accelerating the development of green markets because of its great economic importance and its objective to prioritise green products and services. For example, public procurement can help Nordic innovations attain significant positions more quickly in the Nordic market, thereby increasing exposure and volumes as well as opening the doors to export.

The Nordic Council of Ministers is working actively to promote the use of green criteria in public procurement in the Nordic countries, and is the first international organisation to initiate the formulation of a set of common criteria for green public procurement.

Nordic Cooperation on Green Public Procurement: The First Set of Criteria Examples, ANP 2009:759

www.norden.org/ en/publications/ publikationer/2009-759 


\section{Virtual servers - reality in Denmark}

When the municipality of Copenhagen was to procure new servers, the buyers contacted SKI, National Procurement Ltd. The new agreement ensuing from that will reduce carbon dioxide emissions and costs, while improving quality.

The 638 servers in the municipality of Copenhagen have been replaced with 32 new, interconnected, servers. The new servers are larger and more efficient, so the total server capacity has increased even though the number has been drastically reduced.

The agreement runs for five years, and is a major financial investment. Despite this, the municipality is optimistic of saving money in the long term. The servers are concentrated in one location, which facilitates operation. The cooling system in the server room is optimised in order to cool various locations specifically, which reduces energy needs by around 33 percent. The supplier has also promised to climate-compensate the servers. This is done by the planting of 500 trees in India, which bind carbon dioxide equivalent to the emissions caused by the electricity use of the servers.

The new solution reduces carbon dioxide emissions by 3,550 tonnes. This is 75 percent less than the old servers. In addition the new installation uses less energy and service, thereby saving approximately 200,000 Euro a year. This is a very good example of how quality, environment and economy can go hand-inhand. 


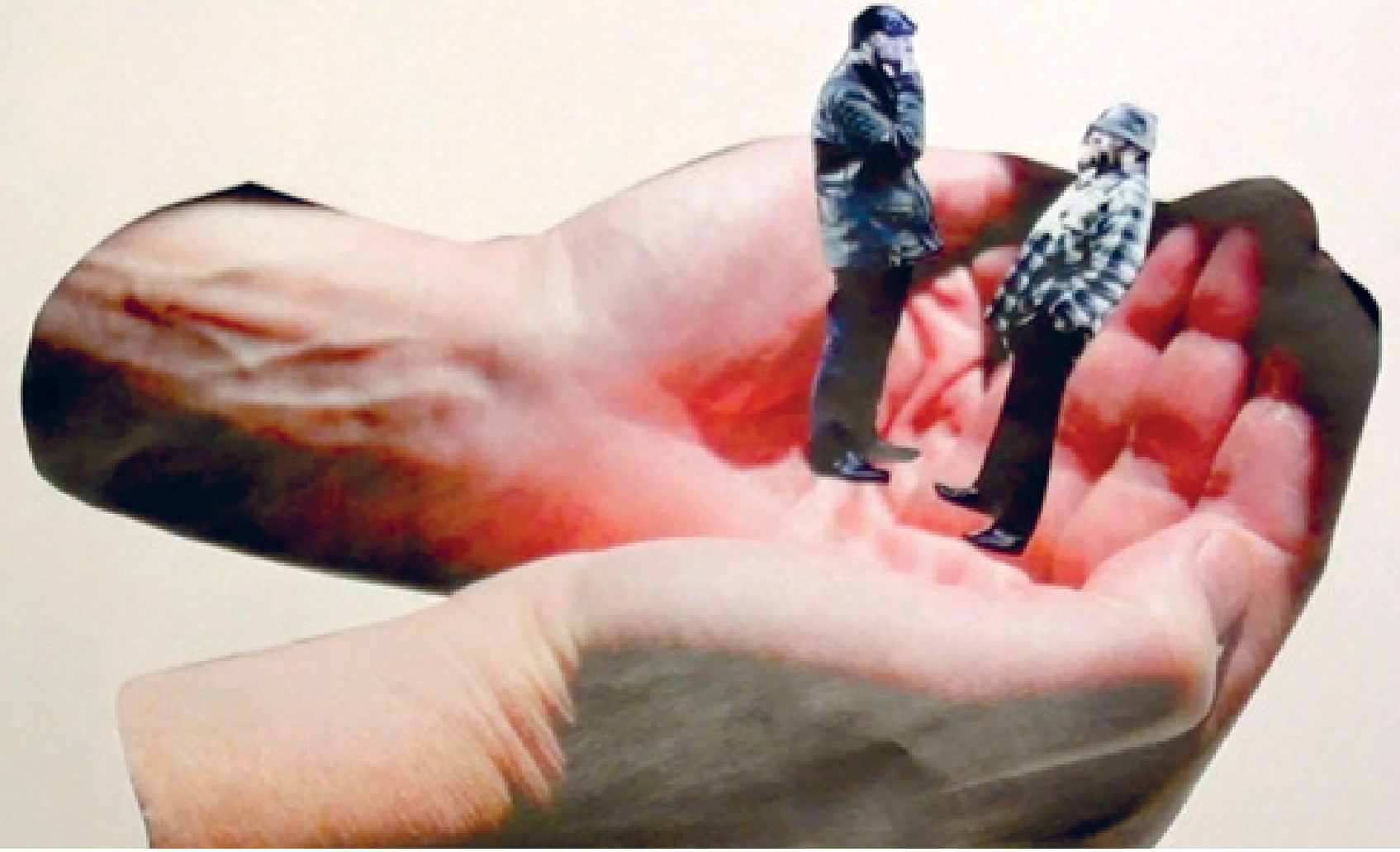




\section{Welfare and sustainable development go hand-in-hand}

The Nordic countries do not approach welfare provision in exactly the same way, but the similarities between the countries are sufficient for us to refer to the "Nordic welfare model". The model is based on democracy, equality, good administration, measures to combat corruption, free education, access and right to health care and social services, and general social insurance, all of which create a platform from which to efficiently promote sustainable development. The Nordic countries have succeeded in combining high income levels, moderate economic growth, a stable economy and social wellbeing.

There are also great similarities between the countries in terms of the challenges that will need to be met in the future. A common task is to identify innovative solutions for meeting challenges like demographic change and globalisation. The Nordic countries also need to ensure that public health is both of a high level and equal, and need to work to prevent relative poverty.

The homogeneous society systems in the Nordic countries make it relatively easy to see what other countries are doing and to gather inspiration from the best examples. The Nordic Council of Ministers is continuously carrying out initiatives to stimulate the exchange of experiences, further development, and collaboration in the welfare policy area. Another important dimension in the welfare work of the Nordic Council of Ministers is to strengthen dialogue and collaboration, both regionally and internationally. This is done through contact with European and international organisations such as the Council of Europe, the WHO, and the Northern Dimension Partnership in Public Health and Social Wellbeing.

\section{Extensive initiatives to im- prove health and welfare}

The Nordic globalisation initiative for health and welfare, The Nordic region as a competitive and unique welfare region - a good region in which to invest, work and live, is a three-year Nordic collaboration programme that has been developed to promote the sustainability and competitiveness of the Nordic welfare model.

The initiative comprises seven projects that, in different ways, will strengthen the position of the Nordic area in the global health and welfare sector. The initiative promotes close collaboration between various sectors to enable the countries to develop efficient solutions in the best possible way.

Two examples of the projects in the initiative:

\section{Integration of vulnerable groups} on the labour market is one of the focus areas. This project will promote greater inclusion of weaker members of society on the Nordic labour market. The target group is young people in the transition from education to work, people with psychological and physical disorders, and older people. Another focus area is recruitment of foreign labour, as well as immigrants' work environment and link to the Nordic labour market. This project will help to increase the numbers of skilled foreign workers in the Nordic area, in order to secure the skills for which there is greatest demand in the labour force in the respective countries.

www.norden.org/healthand welfare

Sustainable Development in Practice 


\section{Joint initiatives against trafficking in human beings} Every year, illegal trafficking of women, men and children takes place over national boundaries. Trafficking in human beings is a complex problem that is closely related to the general globalisation and development trends in the world.

If we are to stop trafficking with human beings, we need common knowledge and understanding of the new forms of organised, criminal exploitation of people that currently prevail. Regional and international collaboration between both public agencies and NGOs is necessary to solve the problems. The Nordic collaboration gives high priority to measures against trafficking of human beings, and is working to strengthen the regional collaboration between northwest Russia, Estonia, Latvia and Lithuania.
In February 2011, the Nordic co-operation ministers adopted a programme to combat trafficking in human beings. The programme comprises five projects and focuses on social aspects of trafficking in human beings. In order to strengthen the regional platform for collaboration between the Nordic countries and their neighbours in the Northern Dimension region, exchange of experiences and dissemination of knowledge over national boundaries are emphasised. The programme has, for example focused on new forms of trafficking in human beings, including forced labour, begging and child labour.

\section{Freedom of movement generates welfare}

Citizens of the Nordic countries enjoy freedom of movement within the region. The work to identify and remove barriers to this freedom of movement, border obstacles, is therefore a key task for the Nordic Council of Ministers. The work to remove these obstacles is part of an overarching strategy to produce a well-functioning inner market in the Nordic area, both for private individuals and for businesses. The economic base, and thereby the welfare societies, of the Nordic countries, is strengthened by maximising access to each other's labour markets and by enabling cross-border business activities.

In June 2007, the Nordic prime ministers decided to "by all means possible remove the barriers that the citizens can encounter in relations with the other Nordic countries". This decision was formalised a year later when a specially-appointed group, the Freedom of Movement Forum, was set up. The Freedom of Movement Forum identifies tangible border obstacles and proposes solutions, and initiates Nordic collaboration on the implementation of EU directives. The forum also holds con- 
sultation meetings when national laws are under preparation. The procedures will prevent countries introducing new laws and regulations that make difficult, or limit, freedom of movement within the Nordic area.
In recent years, initiatives have been implemented to remove a large number of tangible border obstacles, involving taxes and social insurance, as well as business and the labour market. Each year, 5-10 concrete obstacles have been

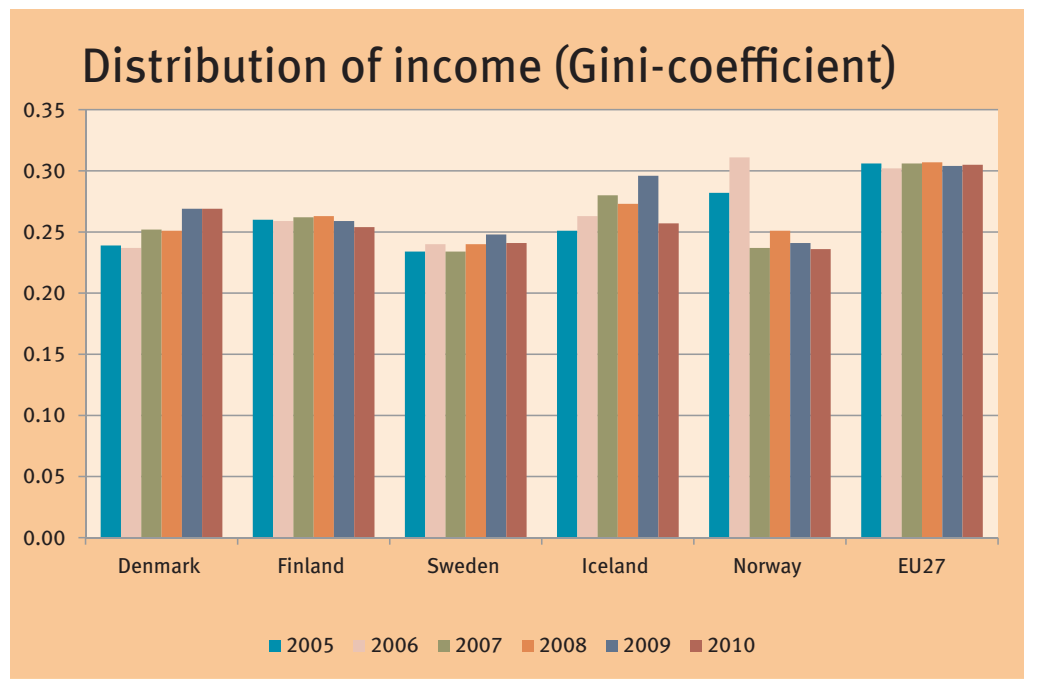

Sustainable Development in Practice

removed. A current issue that has been under examination for some time, and that is now being negotiated at EU level, is that of social insurance affiliation of people who live in one country but who work in two countries simultaneously.

The Nordic countries also have a common information service, hallonorden.org, which offers guidance to primarily private individuals who move between the Nordic countries.

www.norden.org/en/resources 
Knowledge and participation vital for sustainable development

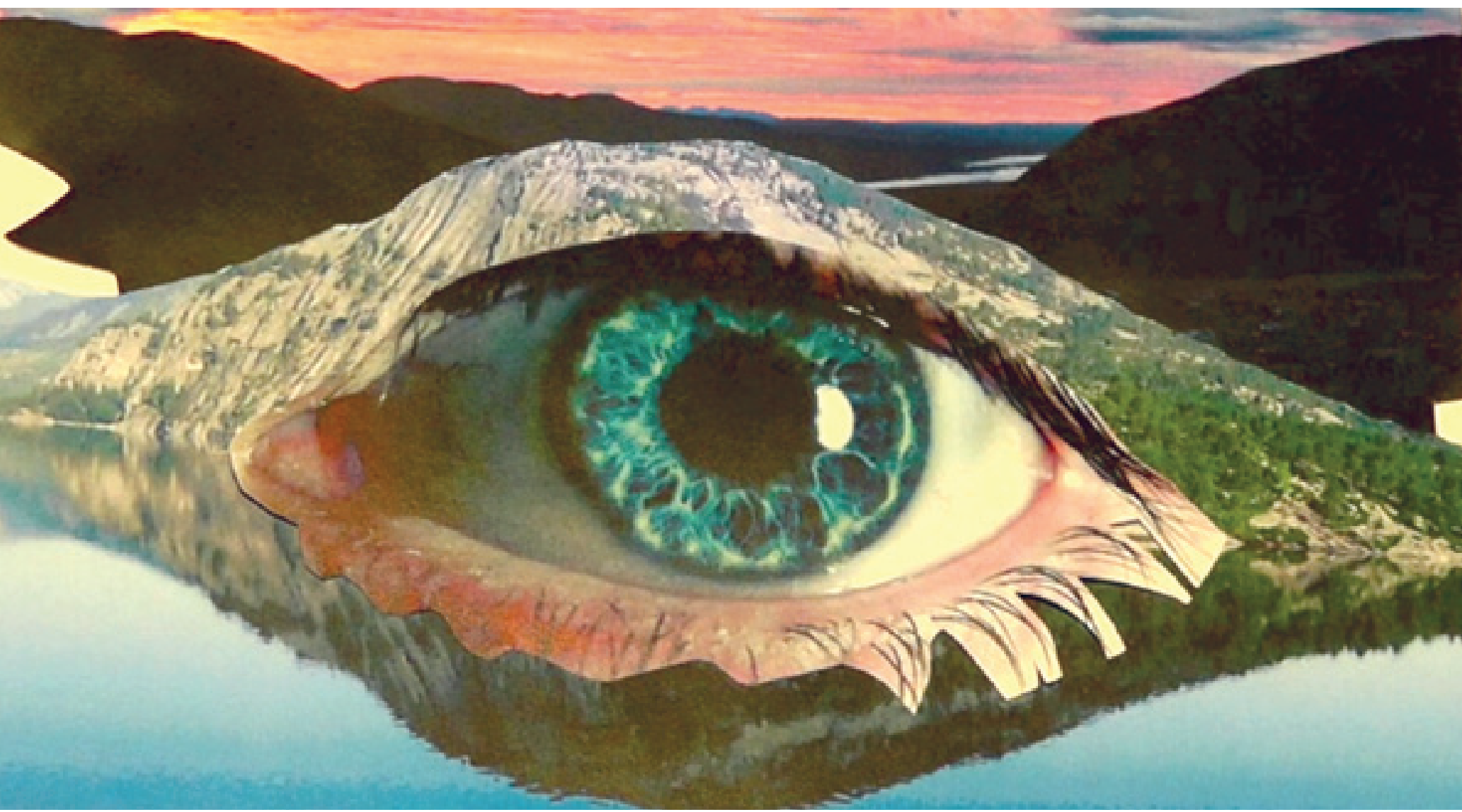


If we are to achieve sustainable development, it is important that everyone can contribute to the work to bring about change. Education and knowledge about sustainable development is one of the keys to the individual citizen being able to actively participate in the change. Consequently, the Nordic countries are working to integrate sustainable development into both primary and secondary education, as well as other educational programmes.

The Nordic countries are pioneers when it comes to local strategies for sustainable development, such as in local Agenda 21 projects. The Nordic Council of Ministers is striving to extend this work, for example by promoting the exchange of experiences between municipalities in the region. The ability of the population to participate and influence the work on sustainability at local level is vital for the transformation to a more sustainable society. The Nordic countries are therefore working to promote the ability of the public to become involved and exercise influence in decision-making processes.

If we are to transform our societies into more sustainable societies, our research and innovation environments must also be equipped to meet the needs for new solutions and knowledge. The Nordic measures in education, research and innovation are therefore designed to promote the production of know-how and technology that supports sustainable development.

\section{The Nordic countries focus on research into climate and energy}

The Top-level Research Initiative is the largest joint Nordic research initiative to date. The initiative is a Nordic flagship project in terms of regional collaboration for research and innovation.

The initiative focuses on climate and energy, and aims to make a Nordic contribution to the solu- tions to the global climate crisis. At the same time, the initiative will strengthen the Nordic area as a research and innovation region. The initiative focuses on the areas in climate and energy research where the Nordic countries have common interests and where they can contribute to solutions internationally. Coordination with the national initiatives in each country is also a key feature.

The Top-level Research Initiative involves participants from all Nordic countries. Two-thirds of the project participants come from the university and research spheres, just under one-third from industry, and just under one-tenth from other areas. This constellation of participants is designed to strengthen the collaboration between leading research environments and industry. The Top-level Research Initiative is a unique project in which the countries supplement the "seed money" from the Nordic Council of Ministers with national funding.

www.toppforskningsinitiativet.org/en 


\section{Nordic Climate Day}

In 2011, the Nordic Climate Day was arranged for the third time. The objective is to engage children and young people in the Nordic countries in the battle to improve the climate, by stimulating pupil and teacher engagement for the climate issue. It is the education ministers in the Nordic countries that invite participants to the Nordic Climate Day, and the target groups are pupils, teachers, trainees and training staff throughout the Nordic region.

As part of the Nordic Climate Day, schools, municipalities, organisations, etc. in the Nordic area are invited to organise their own climate activities. In 2010, for example, Lund University in Sweden collaborated with Lund Youth Forum and Lund municipality to arrange a dialogue between upper-secondary students, researchers, politicians and administrative officers about how emissions from traffic in the Öresund region could be reduced.
The theme for the Nordic Climate Day 2011 was food and climate. One of the focus areas was climate-friendly Nordic products, New Nordic Food, and production and transport of food. In a competition, schools created climatefriendly Nordic snacks. Extracts from the most innovative and thought-provoking contributions were presented in an online Nordic cookbook - a joint-Nordic web publication about climate-friendly food from all over the Nordic area.

www.klimanorden.org

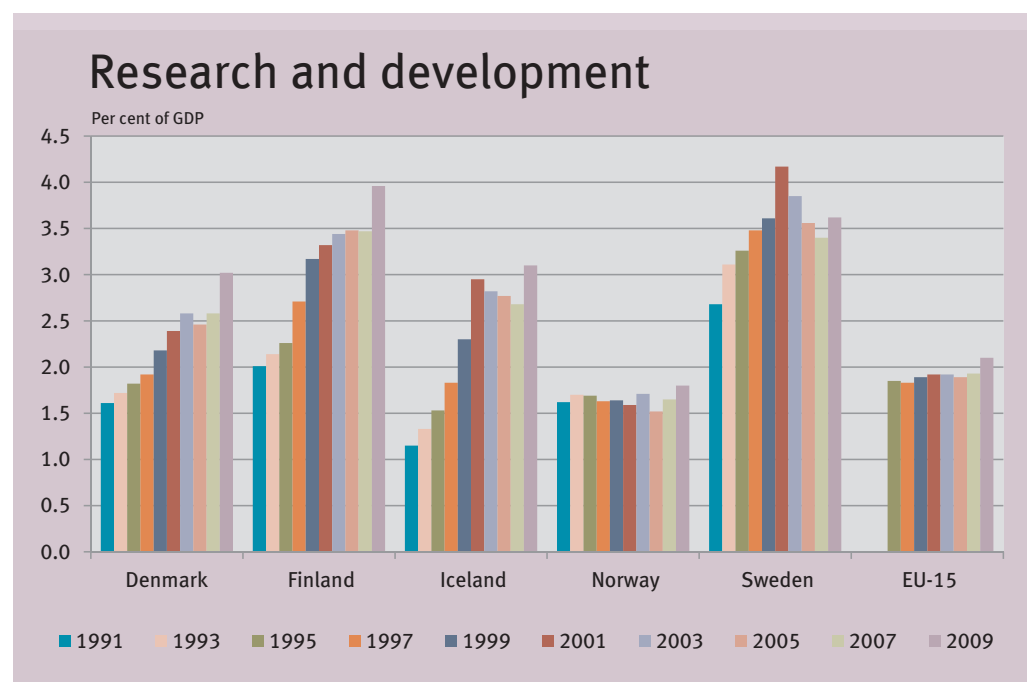




\section{Nordic Master Programme offers top-level studies in sustainable development}

The educational programmes offered under the Nordic Master Programme comprise the best features of higher education in the Nordic countries.

The Master Programme links university courses from at least three Nordic countries in a joint educational programme. By gathering expertise from universities throughout the Nordic area, these programmes can offer Nordic and international students educational courses of the highest quality.

Several of the programmes specialise in studies relating to the environment and sustainable development. Higher education institutions participating in the Nordic Master Programme include the five universities of technology that comprise the Nordic Five Tech.

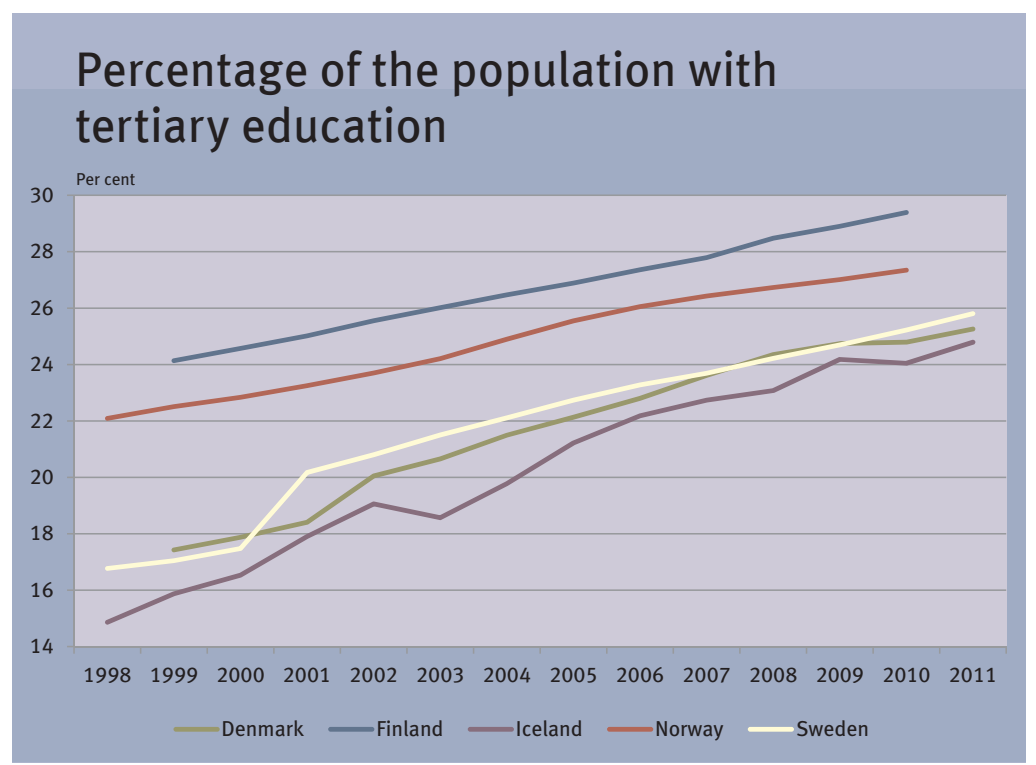

\section{Exchange of ideas, experi- ences and knowledge at the Nordic Sustainability Conference}

Nordic Conference on Sustainable Development aims to strengthen global and local sustainability by collating experiences and ideas from the public sector, the busi- ness community, researchers, politicians, NGOs and citizens in the region, in order to identify measures that will generate sustainable development.

The conferences are held every two or three years at different Nordic locations. The most recent 
conference was held in Turku in Finland at the start of 2011, with the theme Solutions local, togeth$e r$. The conference focused on the importance of strengthening links between economic, social and environmental aspects of sustainable development, in order to create good solutions for local authorities, businesses, communities and individuals.

The objective of the conference was to enable the participants to share positive experiences of innovations and approaches, and to offer practical and feasible ideas to, in particular, municipalities and other players at local level.

Planning of the next Nordic conference is already under way. The conference, The Art of Co-creation will be held in Umeå, Sweden, in 2013.

www.solutions2011.fi www.medskapande2013.se
Landscape architecture with emphasis on sustainability

Biological diversity in an urban context, interaction between infrastructure and landscape, process urbanism, a closer look at Iceland's utilisation of geothermal energy, and the deployment of residues from the Norwegian oil industry.

These were the themes in the joint Nordic exhibition, New Nordic Landscapes, at the world EXPO in Shanghai in 2010. The exhibition focused on the strategic role of landscape architecture in sustainable development, and showed that landscape architecture is about so much more than making things look pretty. Good landscape architecture can help supply sustainable solutions, promote health, and create better living conditions for people in both urban and rural areas.

The exhibition highlighted the importance of finding new and alternative planning methods and strategies that emphasise the conscious use of natural resources, and combine the latest developments in technology and global know-how with an awareness of local conditions, culture and identity. A close relationship with the natural environment and efforts to strike a balance between utilisation, development and protection of natural resources and landscape are traditionally important ingredients in Nordic cultural history. This type of consideration has become even more important in the light of the current environmental challenges. 


\section{Sustainable development in Finland}

Finland has been working on sustainable development since the 1980s. The Finnish National Commission on Sustainable Development, one of the first in the world, was set up in 1993. The Finnish commission is regarded as unique, because it is based on an open dialogue between the government, administrative bodies, the business community and the civil society. On a number of occasions, the commission has raised important themes in the national dialogue, influenced the content of government programmes, and has been involved in creating political agreement on issues that concern sustainable development.

The work in the Finnish National Commission on Sustainable Development is based on the national strategy, Towards Sustainable Choices. A Nationally and Globally Sustainable Finland, from June 2006. The strategy combines the sustainable use, management and protection of natural resources with citizens' wellbeing and social cohesion. Because of the objectives and proposals of the strategy, players in both the public and private sectors, and in the civil society, have developed their own programmes and strategies. Examples are a cross-sectoral action programme for sustainable consumption and production (SCP) and reports on climate and energy policies and a smart and responsible natural resource economy. In addition, a strategy for a socially sustainable society by 2020 has been adopted and several environmental management systems have been implemented.

Finland's sustainability policy has also led to the implementation of practical initiatives. For example, the SCP programme has led to the setting up of a material efficiency centre and promoted sustainable public procurement through government decisions in principle. However, despite all the state measures, the boldest and most innovative solutions often occur at local level. A good example is the Hinku Project, in which five Finnish municipalities undertook to become pioneers - they plan to reduce emissions of greenhouse gases faster than stipulated by the EU targets and the agreed timetable. Within two years, these municipalities have implemented over 70 measures to promote energy efficiency, energy savings, use of renewable natural resources, and environmental investments. The project has demonstrated that, using modern technology, positive involvement can help municipalities attain ambitious climate targets even in their environmental, employment and economic activities. 


\section{For more information, please see the following resources:}

Website on the Nordic co-operation on sustainable development www.norden.org/sd

Nordic indicators for sustainable development www.norden.org/sdindicators

Publications from the Nordic Council of Ministers www.norden.org/en/publications

The newsletter NordicEnvironment www.norden.org/ne

Facebook page on the Nordic co-operation on sustainable development www.facebook.com/sdnordic

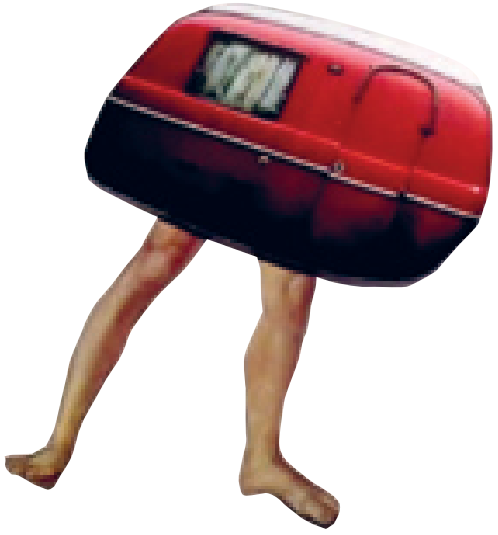




\section{Nordic Council of Ministers}

The Nordic collaboration involves Denmark, Finland, Iceland, Norway and Sweden, and the three autonomous areas, the Faroe Islands, Greenland and Åland. The formalised collaboration between the Nordic countries is one of the oldest and most extensive regional collaborations in the world. The collaboration is based on common values and a desire to attain results that promote dynamic development and that increase the expertise and competitiveness of the Nordic countries.

The Nordic Council of Ministers was formed in 1971 and is the official collaboration body of the Nordic governments. The Nordic prime ministers and the political leaders of the autonomous areas have ultimate responsibility for collaboration within the Nordic Council of Ministers. The government collaboration works for common Nordic solutions that give tangible positive effects, Nordic synergies, for the citizens of the individual Nordic countries and in the three autonomous areas.
Nordic collaboration focuses on areas where joint measures create added value for the individual Nordic countries and their inhabitants. The collaboration includes trade and industry policy, economic and legal issues, social and health policy, as well as equality, working life, and agriculture and forestry. Other important focus areas for Nordic collaboration are climate, environment and energy, research, education and innovation, as well as improved regional integration through removal of border obstacles between the countries.

The results of the joint initiatives of the Nordic countries can be seen in the everyday lives of the Nordic citizens. The collaboration has resulted in, for example, a common Nordic labour market, a passport union and a number of common social regulations. For many years, Nordic citizens have been able to live and study anywhere in the Nordic countries.

www.norden.org 


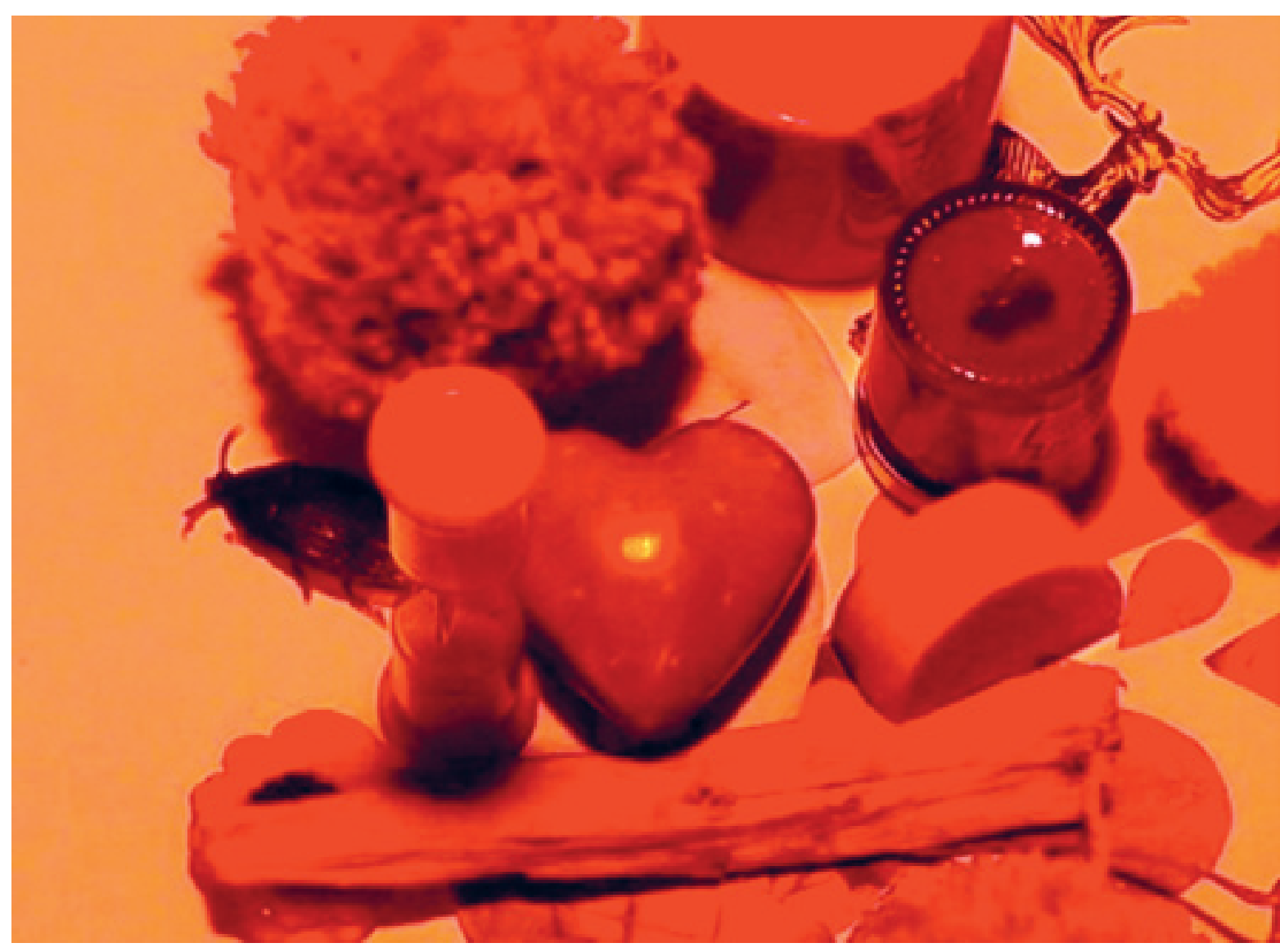




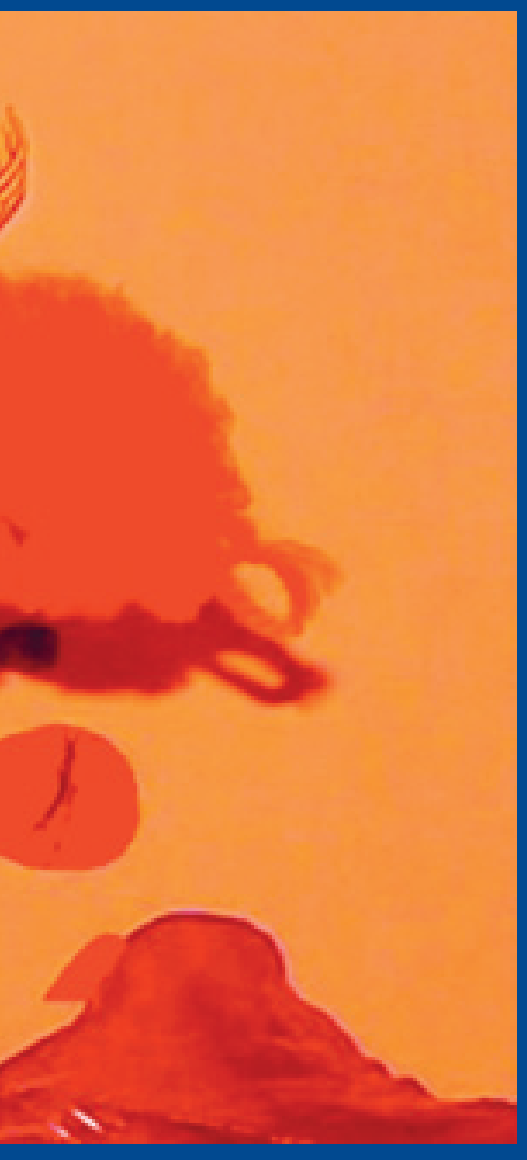




\section{nordan}

Nordic Council of Ministers

Ved Stranden 18

DK-1061 Copenhagen K

www.norden.org

\section{Donate a word}

What is sustainability to you? What does it mean to be human? And what do you connect with the word nature?

We collect words from all over the world to make a global collage of thoughts and ideas on sustainable development.

Join us at

www.norden.org/donateaword

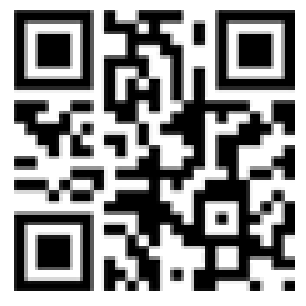

ANP 2012:726

ISBN: 978-92-893-2355-0

DOI: $10.6027 / A N P 2012-726$ 